\title{
Ambasadorul englez al României sălbatice, Charlie Ottley:"Legea silvică în sine nu este rea, dar nu există voință sau finanțarea necesară pentru aplicarea acesteia"
}

\section{Laurențiu Giornei}

Jurnalistul britanic Charlie Ottley este, de aproape un deceniu, unul dintre cei mai perseverenți ambasadori ai imaginii României în lume. Fascinat de frumusețea și naturalitatea țării noastre, Charlie face emisiuni de televiziune, scrie editoriale și reportaje pentru cele mai prestigioase canale media din lume, necontenind să laude măreția și sălbăticia munților Carpați sau biodiversitatea.

Născut în urmă cu 49 de ani la Winchester, în Anglia, Charlie a devenit prieten al României după de a colindat lumea în lung și-n lat spre a descoperi frumuseți. Mereu a fost omul încercat de focul cunoașterii și a căutat să descopere părțile frumoase ale națiilor. Dublu licențiat al Universităţii din Bristol, în teologie și filosofie, Charlie Ottley și-a încercat norocul şi în jurnalism, absolvind și facultatea de profil de la City University din Londra. După un scurt stagiu la Londra, a ajuns șeful biroului de corespondenți de la Los Angeles al grupului media World Entertaiment News Network. Acum, Charlie Ottley scrie constant pentru The Dail Mail, Food and Travel Magazine şi Vanity Fair.

În urmă cu două decenii și-a făcut propria televiziune, Forge TV, filmând reportajele pe care le făcea pentru Daily Express. A călătorit prin lume producând o serie de emisiuni culinare spectaculoase. Astfel, a descoperit "aromele" mâncărurilor din Chile (Flavours of Chile), Columbia, Peru, Mexic, Spania, Grecia, Scoția sau Africa de Sud. Succesul seriei, difuzată pe Travel Channel, a asigurat o nouă

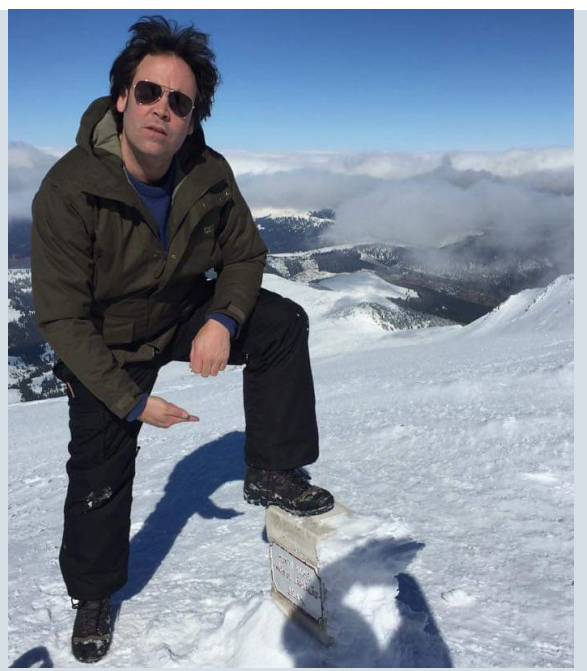

serie bazată pe partea culinară şi de călătorii, intitulată Flavours of Chile. În următorii 12 ani a realizat serii similare în Peru, Spania, Mexic, Scoţia, Africa de Sud, Columbia şi Grecia.

În 2011, Charlie Ottley a venit pentru prima oară în România cu același scop de a descoperi tradiția culinară și de natura. A fost fascinat și de atunci își canalizează eforturile pentru a ajuta la păstrarea bogăţiilor naturale ale României. A realizat celebra seriei de reportaje televizate, Wild Carpathia, difuzată în 110 ţări şi tradusă în 11 limbi. În vara lui 2017, Charlie Ottley a prezentat ultimul episod din Wild Carpathia la sediul ONU din New York, fiind aplaudat la scenă deschisă de reprezentanţii a 193 de ţări şi sute de personalități mondiale prezenți la acel eveniment. 
La finalul anului trecut, ambasadorul României sălbatice și-a cumpărat o casă în Bran și intenționează să o transforme într-un veritabil loc de pelerinaj al prietenilor englezi care, la rândul lor, vor deveni - asemenea lui Charlie "reprezentanți diplomatici" ai României.

1. Ai fost în Chile, Peru, Mexic, Columbia, Africa de Sud, Scoția, Grecia. În toate aceste extraordinare țări ai realizat emisiuni asemănătoare seriei dedicate României. Tara noastră însă te atrage cel mai mult. Care este motivul?

Am vizitat multe țări în decursul celor zece ani ca prezentator Travel Channel, dar tot ce făceam era să încurajez alți oameni să consume și să polueze, fără a face nimic deosebit de benefic. Când am vizitat România, am descoperit frumusețea peisajelor din Carpați, dar am aflat şi despre distrugerea patrimoniului natural şi cultural al acestei țări. Așa că am decis să fac un alt tip de program, unul care ar putea inspira schimbări pozitive nu doar prin turism, ci și prin conservare. Când lucrezi atât de intens într-o țară ajungi să o cunoști, așa că m-am îndrăgostit, treptat, din ce în ce mai mult de România, în ciuda tuturor problemelor pe care le ai aici.

2. Ai câteva locuri pe care le preferi, multe dintre acestea fiind minuni ale naturii, cum sunt Cheile $\mathrm{Ne}$ rei, Rarăul, Corbii de Piatră, Delta. Acestea sunt diferite și oferă imaginea unei palete de diversitate. Asta înseamnă că ai intuit perfect potențialul de diversitate și de biodiversitate pe care îl are România.

Da! Am fost întotdeauna foarte conștient de faptul că România este o mulțime de țări înglobate într-una singură. Frontierele sunt realizate de oameni, dar regiunile au propriile lor identități individuale pe care ar trebui să le respectăm și să le protejăm. Sunt atât de multe de văzut aici, atât de multe peisaje diferite, care toate au propria lor atitudine specială. Ar trebui să le promovăm pe toate, mai degrabă încât să ne concentrăm pe aceleași destinații din ce în ce mai banale.

3. Turismul poate deveni un motor al dezvoltării durabile în zona de munte, acolo unde oportunitățile de susținere a vieții sunt mai limitate. Aș vrea să faci un exercițiu de imaginație și să te gândești că mâine vei fi desemnat să gestionezi un proiect cu această temă: crearea unui sistem integrat pentru implementarea unui tip de turism dedicat zonei montane din România. Care ar fi principalele direcții către care te-ai orienta și punctele-cheie ale acestui proiect?

Primul lucru pe care l-aş face este să desemnez zone cu importanță naturală și culturală deosebită care acoperă sate, orașe istorice, zone sălbatice și apoi să punem în aplicare legi stricte de planificare arhitecturală, astfel încât aceste comori vitale să nu fie distruse de pensiuni urâte de beton și case de vacanță în stil elvețian. Aș obliga ca toate clădirile din aceste zone să fie construite doar folosind materiale tradiţionale, cu design deosebit. Toate planurile noi de construcții ar trebui să fie prezentate spre aprobare unor experți în conservarea culturală care să lucreze împreună cu consiliile locale pentru a ne asigura că nu distrugem integritatea istorică a comunităților rurale, astfel încât să poată beneficia în continuare de turism. Acest lucru se întâmplă în Marea Britanie unde legea asigură ca orașele și satele frumoase să rămână intacte din punct de vedere vizual. În al doilea rând, aş face ca toate exploatările forestiere în parcurile naţionale să fie complet interzise, să replantez cu arbori autohtoni pentru a preveni degradarea şi alunecarea solului cauzată de eroziune. În al

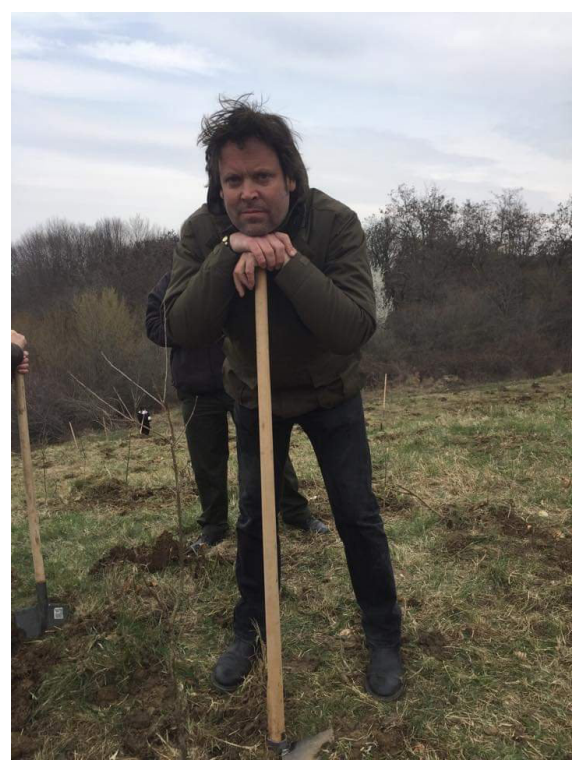


treilea rând, aș crea depozite pentru materiale, subvenţionate de guvern pentru fiecare comunitate, din care localnicii își vor putea cumpăra lemne de foc, împiedicând astfel comerțul cu lemn de foc tăiat ilegal. În al patrulea rând, aș impune amenzi substanțiale oamenilor care își aruncă gunoiul, fie că este domestic sau comercial în locații fără licență. În acest scop, aș înființa, de asemenea, centre de reciclare în toată țara, unde oamenii își vor putea aduce gunoiul domestic gratuit, astfel încât să înlăture ispita de a-l arunca ilegal. De asemenea, aș percepe o taxă de parcare pentru toate parcurile naționale. Aș aloca salarii pentru angajați și pentru plata instalațiilor de gunoi montate lângă locurile de picnic și zonele de parcare, pentru a încuraja oamenii să nu își lase gunoiul în pădure.

În al cincilea rând, aș oferi stimulente fiscale oricui dorește să deschidă o fabrică de mobilă şi subvenţii pentru a instrui studenţii şi ucenicii să învețe meșteșugul din lemn. Acest lucru ar reduce nevoia de a exporta lemn neprocesat și ar crește valoarea lemnului care părăsește România, ceea ce ne-ar permite să exploatăm pădurile cât mai durabil.

În sfârșit, aș oferi gratuit schimburi de bune practici pentru comunitățile locale care să le ajute să beneficieze de turism, fie prin promovarea meșteșugurilor locale, fie prin oferirea de servicii sau cazare.

\section{Am văzut că în România te-a interesat foarte mult și soarta pădurilor. Ce anume ți-a trezit interesul, excep- tând frumusețea acestora?}

Foarte simplu! Pădurile Carpaților sunt plămânii Europei. Acestea sechestrează o cantitate mare de dioxid de carbon și joacă un rol esențial în protejarea împotriva încălzirii globale, fiind cea mai mare pădure sălbatică rămasă din Europa. Acestea reprezintă, de asemenea, habitatul a peste două treimi din prădătorii Europei și au o biodiversitate incredibilă. Aceste păduri nu ar trebui să aparțină niciunei persoane sau vreunui stat, deoarece sunt prea importante pentru supraviețuirea tuturor și a generațiilor următoare. Trebuie să le protejăm sau ne vom face singuri rău.
5. 0 mare parte a societății, încurajată și stârnită de câteva organizații nonguvernamentale care veghează ca starea pădurii să nu fie alterată de ilegalități, consideră că orice bustean transportat pe șosele provine din defrișări. Silvicii se apară și consideră că acuzațiile sunt, în cea mai mare parte, nefondate. În România nu prea au fost judecați hoții mari de lemne. Ce știi despre asta? Cum ți se pare și cum se vede în Marea Britanie acest, să-i spunem conflict, între militanții ecologiști și profesioniștii pădurii?

Majoritatea oamenilor din Marea Britanie știu foarte puțin despre ce se întâmplă aici - ceea ce a devenit cea mai mare criză de mediu din Europa. Problema este că știm cu toții ce se întâmplă aici. Chiar și guvernul a recunoscut faptul că peste 30 de milioane de metri cubi de pădure sunt tăiați ilegal în fiecare an. Aceasta este în afară de ceea ce se exploatează legal. Limita durabilă pentru recoltarea lemnului a fost recent calculată la aproximativ 10 milioane de metri cubi, astfel că să puteți vedea care e problema. ONG-urile au dreptul să facă campanie împotriva acestui lucru, ar trebui să fim cu toții îngroziți că ilegalitățile sunt încă permise. Nu există suficientă voință sau fonduri puse la dispoziție pentru a opri tăierea ilegală. Am putea face asta dacă am vrea, dar nimeni nu vrea. Toate aceste comunităţi mici, precum cele din jurul Borşei, știu cine o face. Întorc ochii către camioanele care trec toată noaptea pe lângă geamurile lor și poliția nu face nimic. Atât timp cât documentele par să fie în regulă, nimeni nu poate fi deranjat și, eventual, anchetat. Însă faptul că documentația şi aprobările sunt acordate deseori de către oficiali corupți, nu cred că sunt în regulă. Marile companii, precum Schweighofer şi Kronospan, nu fac decât să sporească cererea de lemn și, așa cum s-a dovedit prin raportul EIA, au primit deseori lemn provenit ilegal. Trebuie să existe o poliție forestieră independentă, formată din persoane care se află dincolo de orice suspiciune de luare de mită sau intimidare. Acestea să aibă puterea de a da amenzi și de a-i aduce pe cei implicați în tăieri ilegale în fața procurorilor, să fie pedepsiți cu amenzi și pedepse cu închisoarea pentru cei găsiţi vinovați. 
6. Ai cunoștință despre cum se face managementul pădurii în România? Care sunt principalele coordonate după care se ghidează acesta? Crezi că presiunea factorului economic (pădurea să ofere cât mai mulți bani) impietează dezvoltarea durabilă?

Legea silvică în sine nu este rea, dar nu există voință sau finanțarea necesară pentru aplicarea acesteia. Consider că defrișarea pădurilor este letală pentru viitorul și dezvoltarea durabilă a zonelor rurale și va avea ca rezultat nu doar o catastrofă de mediu, ci și un șomaj extins.

7. Care crezi că ar fi soluția ca România să păstreze și administreze cât mai bine ariile naturale protejate? Am putea fi răsplătiți și financiar pentru că avem cele mai întinse și frumoase dintre pădurile primare ale Europei (exceptând Rusia)?

Ar trebui să solicităm subvenții din partea Uniunii Europene pentru punerea în aplicare a unei politici mai bune pentru protejarea resurselor naturale. Statul trebuie să pună la dispoziție mai mulţi bani pentru subvenții și recompense pentru practica durabilă.

8. Sunt câteva organizații și companii din Europa care achiziționează masiv teren forestier în România. Susțin că fac acest lucru pentru păstrarea intactă a pădurii, deși unele exploatează lemnul deja existent. Ce spui despre asta?

$\mathrm{Nu}$ știu decât despre ONG-ul românesc FCC (n.a. - Fundația Conservation Carpathya), care a interzis total vânătoarea de carnivore mari și a oprit toate exploatările e lemn de pe pământul avut în proprietate. Asta pentru a crea cea mai mare rezervație sălbatică din Europa. Aceasta este, clar, un lucru bun. Nu sunt cunosc activitățile altor organizații, dar orice companie sau grupare care permite exploatarea ilegală a resurselor naturale ale României ar trebui pedepsită în mod corespunzător.

9. Carnivorele mari: lupul, râsul, în mod deosebit ursul, s-au înmulțit peste măsură în ultimii trei ani, spun vânătorii. Conservaționiștii susțin în continuare interzicerea „recoltării” acestor animale. Ce părere ai în acest caz?

$\mathrm{Nu}$ există nicio dovadă concretă a numărului animalelor. Putem specula că numărul de pră- dători crește în unele zone și scade în altele. $\mathrm{Cu}$ toate acestea, asociaţia de vânătoare nu este o sursă credibilă de informații, deoarece pot "umfla" numărul de carnivore. În primul rând avem nevoie de un organism neutru și independent care să analizeze cu exactitate numărul de carnivore mari, înainte de a concluziona dacă populațiile s-au mărit. Dacă acestea sunt în creștere, atunci populațiile ar trebui reglementate, sacrificate sau relocate de autorități, fără ca această acțiune să se facă pentru profit sau sport. De asemenea, trebuie avut în vedere și faptul că doar pentru că vedem mai mulţi urși asta nu înseamnă că există mai mulți urși. Pe măsură ce le epuizăm habitatul, le aducem automat mai aproape de oameni, creând astfel impresia că există mai multe animale sălbatice. Este mai mult decât ironic faptul că mai întâi le distrugem casa și apoi facem campanie pentru a le distruge. Le-am micşorat habitatul natural prin propria noastră lăcomie și dintr-o atitudine distructivă. De asemenea, trebuie să educăm oamenii cu privire la modul în care să acceseze fonduri pentru a le compensa pentru daunele cauzate de prădători, astfel încât acestea să nu ajungă să-şi facă singuri dreptate.

10. În ce stadiu se află demersul tău de a-ți achiziționa o casă în România?

Am cumpărat deja o uimitoare casă tradițională, pe care intentionez să o renovez, într-un sat din apropierea Brașovului, între Piatra Craiului și Parcul Naţional Bucegi.

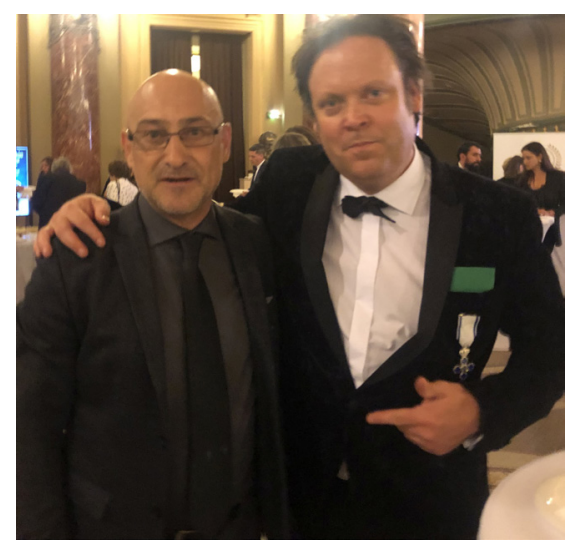

